\title{
Mutants of Pseudomonas facilis Defective in Lithoautotrophy
}

\author{
By JÜRGEN WARRELMANN ${ }^{1}$ AND B ÄRBEL FRIEDRICH ${ }^{2 *}$ \\ ${ }^{1}$ Institut für Mikrobiologie der Universität Göttingen, Grisebachstraße 8, D-3400 Göttingen, \\ Federal Republic of Germany \\ ${ }^{2}$ Freie Universität Berlin (WE 3), Königin-Luise-Straße 12-16, D-1000 Berlin 33, \\ Federal Republic of Germany
}

(Received 26 July 1985; revised 2 September 1985)

\begin{abstract}
Mutants of Pseudomonas facilis impaired in lithoautotrophic metabolism (Aut ${ }^{-}$) were obtained by $\operatorname{Tn} 5$ mutagenesis, mitomycin $\mathrm{C}$ treatment or incubation at sublethal temperature. A colony assay provided a fast screening method for hydrogenase-negative mutants. Three classes of mutants were identified: the first had lost the ability to grow autotrophically with $\mathrm{H}_{2}$ and heterotrophically with $\mathrm{NO}_{3}^{-}$as nitrogen source; the second lacked both hydrogenase and ribulose-1,5-bisphosphate carboxylase activity but nitrate metabolism was unaffected; the third retained the activities of the key enzymes of lithoautotrophic metabolism but failed to grow with $\mathrm{H}_{2}$ and $\mathrm{CO}_{2}$. All of the mutants showed the plasmid pattern of the wild-type.
\end{abstract}

\section{INTRODUCTION}

Hydrogenases are found in many species of bacteria, both aerobic and anaerobic. The molecular properties of these enzymes are rather diverse. According to their physiological function hydrogenases can be subdivided into those that produce $\mathrm{H}_{2}$ and those that consume it (Cammack et al., 1984). The latter type, the so-called uptake hydrogenase, supplies the cell with energy and/or reducing power from $\mathrm{H}_{2}$ (Bowien \& Schlegel, 1981). Several hydrogenases have been characterized biochemically, as reviewed recently by Cammack et al. (1984). Little is known about the genes and the regulation involved in this enzyme system.

Pseudomonas facilis is a Gram-negative, facultatively chemolithoautotrophic bacterium which is able to grow in mineral salts medium under an atmosphere of $\mathrm{H}_{2}, \mathrm{O}_{2}$ and $\mathrm{CO}_{2}$. $\mathrm{CO}_{2}$ is assimilated via the Calvin cycle, the key reaction of which is catalysed by ribulose-1,5bisphosphate carboxylase (RuBPCase), and $\mathrm{H}_{2}$ is oxidized by an uptake hydrogenase. $P$. facilis is a member of the major physiological group of hydrogen bacteria which is characterized by the possession of a single, membrane-bound, respiratory-chain-linked hydrogenase (Schneider \& Schlegel, 1977).

Indirect evidence has been presented for a plasmid location of hydrogenase genes in $P$. facilis (Pootjes, 1977), which is the host of a relatively large plasmid of about $230 \mathrm{MDa}$ (Gerstenberg et al., 1982). However, plasmid-encoded hydrogenase genes have been conclusively identified only in Alcaligenes eutrophus (Andersen et al., 1981; Friedrich et al., 1981a) and Rhizobium leguminosarum (Brewin et al., 1980). $\mathrm{CO}_{2}$ fixation genes are also associated with the indigenous megaplasmid of A. eutrophus (Andersen \& Wilke-Douglas, 1984; Bowien et al., 1984). Hydrogenase genes in Escherichia coli (Krasna, 1984), R. japonicum (Haugland et al., 1984) and Azotobacter chroococcum (Yates \& Robson, 1985) have not been reported to be plasmid encoded.

Genetic investigations of the particulate hydrogenase of $A$. eutrophus were complicated by the fact that mutants impaired in that activity were not altered phenotypically. They grew with $\mathrm{H}_{2}$ as fast as the wild-type due to the functioning of the soluble, NAD-reducing hydrogenase

Abbreviations: RuBPCase, ribulose-1,5-bisphosphate carboxylase; NB, nutrient broth; Km, kanamycin; TTC, 2,3,5-triphenyltetrazolium chloride. 
(Schink \& Schlegel, 1978; Hogrefe et al., 1984). This prompted us to initiate studies with hydrogen bacteria which contain only the membrane-bound enzyme.

In this communication we report the isolation and characterization of lithoautotrophically defective mutants of $P$. facilis and describe different procedures of mutagenesis and screening.

\section{METHODS}

Bacterial strains. P. facilis (DSM 550, ATCC 17695) and A. eutrophus H16 (DSM 428, ATCC 17699) were obtained from the Deutsche Sammlung von Mikroorganismen (DSM), Göttingen, Federal Republic of Germany. Escherichia coli strains SM10 and S17-1 carrying pSUP5011 were used for transposon mutagenesis (Simon et al., 1983).

Media and growth conditions. The bacteria were grown either in nutrient broth (NB) or in mineral salts medium as described by Schlegel et al. (1961) with $\mathrm{NH}_{4} \mathrm{Cl}(0.2 \%)$ as nitrogen source. Organic carbon substrates were supplied at a concentration of $0.4 \%$. An atmosphere of $\mathrm{H}_{2} / \mathrm{O}_{2} / \mathrm{CO}_{2}(8: 1: 1$, by vol.) was used to provide autotrophic growth conditions. Growth experiments were done at $30{ }^{\circ} \mathrm{C}$ on a rotary shaker with $30 \mathrm{ml}$ cultures in $300 \mathrm{ml}$ side-arm flasks. Growth was measured with a Klett-Summerson colorimeter equipped with a 520 to $540 \mathrm{~nm}$ filter.

Mutagenesis. $P$. facilis was grown in NB medium in the presence of the mutagen mitomycin $\mathrm{C}(0.05$ to $0.5 \mu \mathrm{g} \mathrm{ml}^{-1}$ ) for 24 to $72 \mathrm{~h}$. The cells were washed with NB medium and plated onto NB agar.

For transposon mutagenesis the method of Srivastava et al. (1982) was modified as follows: Tn5-mob was transferred from $E$. coli SM 10 or S17-1 to $P$. facilis by the vector plasmid pSUP5011 containing a P-type-specific recognition site for mobilization in Tn5. This plasmid is unable to replicate in hosts other than E. coli (Simon et al., 1983). Kanamycin $(\mathrm{Km})$-resistant colonies were selected on mineral medium containing fructose and $80 \mu \mathrm{g} \mathrm{Km} \mathrm{ml}^{-1}$.

Mutant detection. The simplest, although laborious, procedure for mutant identification was the transfer to mineral agar of single colonies obtained after mutagenesis. The plates were incubated under $\mathrm{H}_{2} / \mathrm{O}_{2} / \mathrm{CO}_{2}$. Growth was examined after 4 to $5 \mathrm{~d}$ incubation.

Hydrogenase-negative mutants of $P$. facilis could be identified by the specific colony staining technique of Schlegel \& Meyer (1985). The assay was modified as follows. After mutagenesis, cells were plated on mineral agar containing $0.1 \%$ glycerol and incubated for 5 to $6 \mathrm{~d}$. The plates were sprayed with 2 to $3 \mathrm{ml}$ of a dye solution consisting of 2 vols $4 \%(\mathrm{w} / \mathrm{v})$ 2,3,5-triphenyltetrazolium chloride (TTC) and 1 vol. $0 \cdot 2 \mathrm{M}$-monoiodoacetate, both dissolved in $35 \mathrm{~mm}$-phosphate buffer. The two solutions were mixed before use, and the $\mathrm{pH}$ was adjusted to 7.0. The plates were incubated for $1 \mathrm{~h}$ under an atmosphere of $\mathrm{H}_{2}$. Hydrogenase-containing colonies turned purple-red due to $\mathrm{H}_{2}$-dependent TTC reduction whereas hydrogenase-free cells remained unstained. Kanamycin-containing plates were incubated under $\mathrm{H}_{2}$, with complete exclusion of $\mathrm{O}_{2}$, achieved by the addition of a gas pack (Anaerocult; Merck).

Enzyme assays. Whole cells were used to determine the activity of key enzymes of lithoautotrophic metabolism. The growth conditions are specified in Results and Discussion. Membrane-bound hydrogenase activity was measured by $\mathrm{H}_{2}$-dependent methylene blue reduction (Schink \& Schlegel, 1979), modified as follows. Cells were washed and resuspended in $50 \mathrm{~mm}$-phosphate buffer, $\mathrm{pH} 7 \cdot 0$. The $\mathrm{OD}_{436}$, measured with a Zeiss PL4 spectrophotometer, was adjusted to 30 . The assay mixture contained $2.9 \mathrm{ml} 0.17 \mathrm{~mm}$-methylene blue in $50 \mathrm{~mm}$ potassium phosphate buffer, $\mathrm{pH} 7 \cdot 0$, saturated with $\mathrm{H}_{2}$. The reaction was initiated by the addition of cells. The cuvettes were incubated anaerobically at $30^{\circ} \mathrm{C}$, and the decrease in $A_{570}$ was followed. Controls were run routinely by substituting $\mathrm{N}_{2}$ for $\mathrm{H}_{2}$ gas.

RuBPCase (EC 4.1.1.39) was determined according to Leadbeater et al. (1982). One unit (U) of enzyme activity is defined as $1 \mu \mathrm{mol}$ substrate converted or product formed $\mathrm{min}^{-1}$. Protein was determined by the Lowry method.

Immunodiffusion experiments. The presence of hydrogenase antigen in the membrane fraction was determined by double immunodiffusion in Ouchterlony plates (Friedrich et al., 1981 a). Cells were subjected to ultrasonic disruption $(0.5 \mathrm{~min}$ treatments per $\mathrm{ml}$ of cell suspension, amplitude 10$)$ in an MSE sonicator. The soluble and particulate fractions of the extract were separated by centrifugation. Membrane extracts were obtained by solubilizing the particulate fraction as described by Schink \& Schlegel (1980). Purified antiserum raised against the particulate hydrogenase of $A$. eutrophus $\mathrm{H} 16$ was provided by H. G. Podzuweit and K. Schneider (Institut für Mikrobiologie, Göttingen, FRG).

Analysis of plasmid DNA. Crude lysates were prepared by the method of Kado \& Liu (1981), modified as described by Hogrefe \& Friedrich (1984). Lysates were analysed by agarose gel electrophoresis as described by Friedrich et al. (1981 a). Purification of plasmid DNA and endonuclease digestion were done as reported by Hogrefe \& Friedrich (1984)

Chemicals. Mitomycin C, kanamycin sulphate and agarose type V were obtained from Sigma. Ribulose 1,5bisphosphate was a gift from G. Whitesides (Harvard University, Cambridge, Mass., USA). $\mathrm{NaH}^{14} \mathrm{CO}_{3}$ was from Amersham. Other chemicals were purchased from Merck. 
Table 1. Hydrogenase and RuBPCase activities in P. facilis

\begin{tabular}{lcrrrrrrr}
$\begin{array}{l}\text { Growth } \\
\text { substrate }\end{array}$ & $\begin{array}{c}\text { Doubling time } \\
\text { (h) }\end{array}$ & & \multicolumn{4}{c}{$\begin{array}{c}\text { Specific activity } \\
\text { Hydrogenase }\end{array}$ (mg protein) $\left.^{-1}\right]^{*}$} \\
$\mathrm{H}_{2} / \mathrm{O}_{2} / \mathrm{CO}_{2}$ & $24 \cdot 0$ & & & \multicolumn{3}{c}{ RuBPCase } \\
Pyruvate & $4 \cdot 2$ & 125 & 1765 & 1995 & 89 & 105 & 106 \\
Succinate & $3 \cdot 3$ & 76 & 74 & 32 & 0 & 0 & 0 \\
Fructose & $3 \cdot 5$ & 99 & 192 & 153 & 0 & 0 & 0 \\
Gluconate & $5 \cdot 5$ & 458 & 476 & 444 & 0 & 0 & 0 \\
Glycerol & $8 \cdot 5$ & 504 & 471 & 218 & 0 & 0 & 0
\end{tabular}

\footnotetext{
* The first value represents the activity of cells taken from the mid-exponential phase, followed by values from the early and the late stationary phase of growth. Each number is the mean value of three independently conducted assays.
}

\section{RESULTS AND DISCUSSION}

\section{Formation of key lithoautotrophic enzymes}

To characterize lithoautotrophically deficient $\left(\mathrm{Aut}^{-}\right)$mutants, conditions had to be defined which allowed the expression of the key enzymes independent of growth with $\mathrm{H}_{2}$ and $\mathrm{CO}_{2}$. Hence, $P$. facilis wild-type was cultivated heterotrophically on organic substrates such as succinate and fructose, which supported fast growth, or glycerol and gluconate, which supported slow growth (Table 1). The activity of hydrogenase was determined at different stages of growth and was found to be present under both autotrophic and heterotrophic conditions. Slowly growing cells had relatively high hydrogenase activity whereas the enzyme activity was low in rapidly growing cells. On organic substrates a decrease in hydrogenase activity was observed when the cells entered the late stationary phase of growth. RuBPCase activity was only detected in cells cultivated autotrophically with $\mathrm{H}_{2}$, and remained constant over a wide period of time (Table 1).

The increased hydrogenase activity in slowly growing cells of $P$. facilis is consistent with data obtained with $A$. eutrophus, in which high hydrogenase activities are achieved under conditions of limited energy supply (Friedrich et al., 1981b), starvation for electron donors being the regulatory signal of hydrogenase derepression (Friedrich, 1982).

\section{Lithoautotrophically defective mutants}

The fact that little is known about hydrogenase genes and their regulation is mainly due to the absence of a suitable procedure for the isolation of mutants. Strains of $P$. facilis which failed to grow with $\mathrm{H}_{2}$ and $\mathrm{CO}_{2}$ were detected at a frequency of $0.2 \%$ among cells which had been grown at a sublethal temperature of $39^{\circ} \mathrm{C}$ or treated with mitomycin $\mathrm{C}$. Transposon $\mathrm{Tn} 5$ provided an efficient tool to generate Aut $^{-}$mutants (Table 2). Km-resistant colonies of $P$. facilis occurred at a frequency of $2 \times 10^{-6}$ per donor cell in matings with $E$. coli S17-1/pSUP5011 or Sm $10 /$ pSUP $5011 ; 0.4-0.5 \%$ of the Km-resistant colonies were Aut ${ }^{-}$mutants.

Mutants specifically impaired in $\mathrm{H}_{2}$ metabolism were identified by a colony staining assay with TTC as electron acceptor in a $\mathrm{H}_{2}$-dependent reduction reaction. This assay was particularly useful for the detection of $\mathrm{Tn} 5$-induced mutants. $\mathrm{Km}$-resistant colonies were selected under hydrogenase-derepressing conditions on glycerol-containing agar and subsequently screened for hydrogenase activity. TTC eliminated the need to test every presumptive mutant biochemically for enzyme activity. Although the procedure is relatively simple it is important to note that consistent dye reduction was only observed under conditions of hydrogenase derepression. Care must also be taken to avoid non-specific reduction of TTC which was observed with cells grown at a substrate concentration exceeding $0 \cdot 1 \%$. This was easily achieved by growing the cells under glycerol-limitation $(0 \cdot 1 \%)$ that allowed derepressed hydrogenase synthesis and simultaneously decreased non-specific reduction of TTC. The method was further improved by inhibiting intermediary metabolism by monoiodoacetate as recently described by Schlegel \& Meyer (1985), and by excluding oxygen which is a competitive electron acceptor of TTC. 
Table 2. Lithoautotrophically defective mutants of $P$. facilis

\begin{tabular}{|c|c|c|c|c|c|}
\hline \multirow[b]{2}{*}{ Strain } & \multirow{2}{*}{$\begin{array}{l}\text { Mutagen/ } \\
\text { mutagenic treatment }\end{array}$} & \multicolumn{2}{|c|}{ Growth on:* } & \multicolumn{2}{|c|}{$\begin{array}{c}\text { Specific activity } \\
{\left[\mathrm{mU}(\mathrm{mg} \text { protein })^{-1}\right] \dagger}\end{array}$} \\
\hline & & $\mathrm{H}_{2} / \mathrm{CO}_{2} / \mathrm{O}_{2}$ & Nitrate & Hydrogenase & RuBPCase \\
\hline Wild-type & None & + & + & 760 & 90 \\
\hline JF19 & & - & - & 0 & 0 \\
\hline JF46 & & - & - & 0 & 0 \\
\hline JF42 & & - & + & 0 & 0 \\
\hline JF43 & Ins & - & + & 0 & 0 \\
\hline JF78 & & - & + & 0 & 0 \\
\hline JF26 & & - & + & 920 & 77 \\
\hline JF9 & & - & + & 1030 & 94 \\
\hline JF11 & Mitomycin C & - & + & 990 & 102 \\
\hline JF4 & Growth & - & + & 920 & 120 \\
\hline JF6 & at $39^{\circ} \mathrm{C}$ & - & + & 840 & 117 \\
\hline
\end{tabular}

${ }^{*}+$, growth; - , no growth. Nitrate served as the nitrogen source in the presence of fructose as the carbon source.

† Hydrogenase activity was determined in cells cultivated in glycerol-mineral medium for $4 \mathrm{~d}$. RuPBCase activity was determined in cells pregrown in fructose-mineral medium for $1 \mathrm{~d}$ under air and shifted to an atmosphere of $\mathrm{H}_{2} / \mathrm{O}_{2} / \mathrm{CO}_{2}$ for $4 \mathrm{~d}$. The numbers are mean values of three independently conducted assays.

Three phenotypically different classes of Aut ${ }^{-}$mutants were discovered (Table 2). Among the Tn5-induced mutants we detected Aut $^{-}$isolates which also failed to use nitrate as a nitrogen source $\left(\mathrm{Nit}^{-}\right)$under heterotrophic conditions. These pleiotropic mutants are represented by strains JF19 and JF46 (Table 2). Aut ${ }^{+}$revertants simultaneously recovered the ability to grow with nitrate; likewise, reversion to $\mathrm{Nit}^{+}$led to the reconstitution of the $\mathrm{Aut}^{+}$phenotype. All of the revertants were $\mathrm{Km}$-sensitive, indicating the excision of the transposon. The data are consistent with the notion that the pleiotropic strains resulted from a single mutation. The occurrence of similar pleiotropic, hydrogenase-deficient mutants has been described for $A$. eutrophus. The possibility has been discussed that these mutants suffer from a lesion in a regulatory gene whose product is necessary for the expression of genes involved in hydrogen and nitrate metabolism (Hogrefe et al., 1984). Moreover, mutants of $E$. coli $\mathrm{K} 12$ have been isolated which were simultaneously affected in nitrate reductase, nitrite reductase, fumarate reductase, hydrogenase activity and in cytochrome C-552 production (Chippaux et al., 1978).

The pleiotropic Aut ${ }^{-}$mutants had lost both hydrogenase and RuBPCase activities. Since there is immunological cross-reactivity between the hydrogenase of $P$. facilis and antiserum raised against the particulate hydrogenase from A. eutrophus (Schink \& Schlegel, 1980; Fig. 1a), we were able to use immunological techniques to further characterize the Aut mutants of $P$. facilis. The pleiotropic mutants were immunologically active (Fig. 1 , wells 1 and 5). However, the cross-reaction was not completely identical with that of the parental strain (Fig. 1b). Thus we assume that the hydrogenase protein of the pleiotropic mutants is at least structurally different from the wild-type enzyme.

A second class of $\mathrm{Aut}^{-}$mutants, represented by strains JF42, JF43 and JF78, was exclusively impaired in lithoautotrophic metabolism (Table 2). Neither hydrogenase nor RuBPCase activities could be detected. Immunological studies of the membrane fraction showed two precipitin bands one of which was identical with that of the wild-type (Fig. 1b, wells 2 and 4).

The absence of RuBPCase activity in cells of all hydrogenase-negative mutants tested so far may reflect a regulatory problem of expressing the $\mathrm{CO}_{2}$ fixing enzymes under conditions where hydrogen is not metabolized. We have shown that the wild-type had hydrogenase activity when cultivated heterotrophically. However, RuBPCase activity was only measurable in cells grown either lithoautotrophically or mixotrophically.

A third class of Aut $^{-}$mutants, including the Tn5-induced strain JF26, had hydrogenase and RuBPCase activities (Table 2). The biochemical lesion of these mutants is still unknown. 

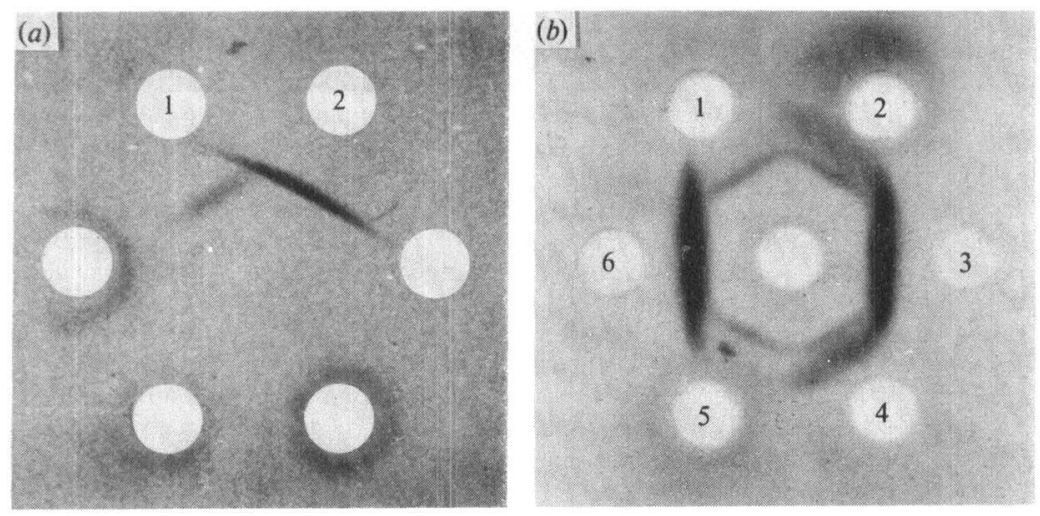

Fig 1. Double-diffusion immunoprecipitation. The centre well contained $4 \mu \mathrm{l}(a)$ or $8 \mu \mathrm{l}(b)$ of antiserum raised against the particulate hydrogenase of $A$. eutrophus. The outer wells of $(a)$ contained $14 \mu \mathrm{l}$ of the membrane fraction of $P$. facilis (1) and A. eutrophus $\mathrm{H} 16(2)$; the outer wells of $(b)$ contained $20 \mu \mathrm{l}$ of the membrane fraction of $P$. facilis wild-type $(3,6)$ and of the hydrogenase mutants JF 19 (1), JF42 (2), JF43 (4) and JF46 (5).

Analysis of plasmid DNA from lysates of the Aut ${ }^{-}$mutants indicated neither a loss nor an alteration in the restriction map of the plasmids (data not shown). Moreover, preliminary hybridization studies revealed a transposon location in the chromosomal DNA and not in the plasmid (Warrelmann, unpublished result). Pootjes (1977) concluded that the high genetic instability of the hydrogen-oxidizing ability of $P$. facilis may result from the curing of a hydrogenase-encoding plasmid. Our results do not support this conclusion. The final identification and cloning of hydrogenase genes from $P$. facilis will be facilitated in the future by the availability of Tn5-labelled hydrogenase mutants. This will answer the controversial question as to whether extrachromosomal DNA is involved in the lithoautotrophic metabolism of $P$. facilis.

We thank H. G. Podzuweit and K. Schneider for the supply of hydrogenase antiserum and Ute Warnecke for the isolation of some of the mutants. We also thank Waltraud Kues for typing the manuscript.

\section{REFERENCES}

Andersen, K. \& Wilke-Douglas, M. (1984). Construction and use of a gene bank of Alcaligenes eutrophus in the analysis of ribulose bisphosphate carboxylase genes. Journal of Bacteriology 159, 973978.

Andersen, K., TaIt, R. C. \& King, W. R. (1981). Plasmids required for utilization of molecular hydrogen by Alcaligenes eutrophus. Archives of Microbiology 129, 384-390

Bowien, B. \& SChlegel, H. G. (1981). Physiology and biochemistry of aerobic hydrogen-oxidizing bacteria. Annual Review of Microbiology 35, 405-452.

BOWIEN, B., FrIEDRICH, B. \& FrIEDRICH, C. G. (1984). Involvement of megaplasmids in heterotrophic derepression of the carbon dioxide assimilating enzyme system in Alcaligenes spp. Archives of Microbiology 139, 305-310.

Brewin, N. J., DeJong, T. M.. Phillips, D. A. \& Johnston, A. W. B. (1980). Co-transfer of determinants for hydrogenase activity and nodulation ability in Rhizobium leguminosarum. Nature, London 288, 77-79.
Cammack, R., Hall, D. O. \& RaO, K. K. (1984) Hydrogenases: structure and applications in hydrogen production. In Microbial Gas Metabolism. Mechanistic, Metabolic and Biotechnological Aspects, pp. 75-102. Edited by R. K. Poole \& C. Dow. New York: Academic Press.

Chippaux, M., Giudici, D., Abou-Jaoudé, A., Casse, F. \& PASCAL, M. C. (1978). A mutation leading to the total lack of nitrite reductase activity in Escherichia coli K12. Molecular and General Genetics 160, 225 229.

FriedRICH, C. G. (1982). Derepression of hydrogenase during limitation of electron donors and derepression of ribulose-bisphosphate carboxylase during carbon limitation of Alcaligenes eutrophus. Journal of Bacteriology 149, 203-210.

Friedrich, B., Hogrefe, C. \& Schlegel, H. G. (1981a). Naturally occurring genetic transfer of hydrogen-oxidizing ability between strains of Alcaligenes eutrophus. Journal of Bacteriology 147, 198205.

Friedrich, C. G., Friedrich, B. \& Bowien, B. 
$(1981 b)$. Formation of enzymes of autotrophic metabolism during heterotrophic growth of Alcaligenes eutrophus. Journal of General Microbiology 122 , $69-78$.

GerstenberG, C., Friedrich, B. \& Schlegel, H. G. (1982). Physical evidence for plasmids in autotrophic, especially hydrogen-oxidizing bacteria. $A r-$ chices of Microbiology 133, 90-96.

Haugland, R. A., Cantrell, M. A., Beaty, J. S., Hanus, F. J., Russel, S. A. \& Evans, H. J. (1984). Characterization of Rhizobium japonicum hydrogen uptake genes. Journal of Bacteriology 159, 1006 1012.

Hogrefe, C. \& Friedrich, B. (1984). Isolation and characterization of megaplasmid DNA from lithoautotrophic bacteria. Plasmid 12, 161-169.

Hogrefe, C., RömermanN, D. \& Friedrich, B. (1984). Alcaligenes eutrophus hydrogenase genes (Hox). Journal of Bacteriology 158, 43-48.

KaDO, C. J. \& LIU, S. T. (1981). Rapid procedure for detection and isolation of large and small plasmids. Journal of Bacteriology 145, 1365-1373.

KrasNa, A. I. (1984). Mutants of Escherichia coli with altered hydrogenase activity. Journal of General Microbiology 130, 779-787.

Leadbeater, L., Siebert, K., Schobert, P. \& Bowien, B. (1982). Relationships between activities and protein levels of ribulose-bisphosphate carboxylase and phosphoribulokinase in Alcaligenes cutrophus. FEMS Microbiology Letters 14, 263-266.

Pootjes, C. F. (1977). Evidence for plasmid coding of the ability to utilize hydrogen gas by Pseudomonas facilis. Biochemical and Biophysical Research Communications 76, 1002-1006.

Schink, B. \& Schlegel, H. G. (1978). Mutants of
Alcaligenes eutrophus defective in autotrophic metabolism. Archives of Microbiology 117, 123-129.

SchinK, B. \& SCHLEGEL, H. G. (1979). The membranebound hydrogenase of Alcaligenes eutrophus. Biochimica et biophysica acta 567, 315-324.

SchinK, B. \& Schlegel, H. G. (1980). The membranebound hydrogenase of Alcaligenes eutrophus. II. Localization and immunological comparison to other hydrogenase systems. Antonie van Leeuwenhoek 46, $1-14$

Schlegel, H. G., Kaltwasser, H. \& Gottschalk, G. (1961). Ein Submersverfahren zur Kultur wasserstoffoxidierender Bakterien; wachstumsphysiologische Untersuchungen. Archiv für Mikrobiologie 38, 209-222.

SChlegel, H. G. \& MeYer, M. (1985). Isolation of hydrogenase regulatory mutants of hydrogen-oxidizing bacteria by a colony screening method. Archives of Microbiology 141, 377-383.

SCHNEIDER, K. \& SCHLEGEL, H. G. (1977). Localisation and stability of hydrogenases from aerobic hydrogen bacteria. Archives of Microbiology 112, 229-238.

Simon, R., Priefer, U. \& PüHLER, A. (1983). Vector plasmids for in-vivo and in-vitro manipulations of Gram-negative bacteria. In Molecular Genetics of the Bacteria-Plant Interaction, pp. 98-106. Edited by A. Pühler. Berlin: Springer-Verlag.

Srivastava, S., Urban, M. \& Friedrich, B. (1982). Mutagenesis of Alcaligenes eutrophus by insertion of the drug-resistance transposon $\operatorname{Tn} 5$. Archives of Microbiology 131, 203-207.

YATES, M. G. \& Robson, R. L. (1985). Mutants of Azotobacter chroococcum defective in hydrogenase activity. Journal of General Microbiology 131, 1459 1466. 